\title{
Billing of Nursing Procedures at An Intensive Care Unit
}

\author{
Raquel Silva Bicalho Zunta ${ }^{1}$ \\ Valéria Castilho ${ }^{2}$
}

This study aimed to: estimate the billing of nursing procedures at an intensive care unit and calculate how much of total ICU revenues are generated by nursing. An exploratorydescriptive, documentary research with a quantitative approach was carried out. The study was performed at a general ICU of a private hospital in the city of Sao Paulo. The sample consisted of 159 patients. It was concluded that the nursing procedures were responsible for $15.1 \%$ of total ICU revenues, which breaks down to an average $11.3 \%$ of revenues coming from nursing prescriptions and $3.8 \%$ from medical prescriptions. Demonstrating how much nursing contributes to hospital revenues is essential information for nursing managers, as it is an important argument to obtain resources and guarantee safe care.

Descriptors: Nursing; Health Care Costs; Hospital Costs.

\footnotetext{
${ }^{1}$ RN, M.Sc. in Nursing, Hospital São Luiz, Unidade Itaim, São Paulo, SP, Brazil. E-mail: rsbzunta@ig.com.br.

${ }^{2}$ RN, Ph.D. in Nursing. Associate Professor, Escola de Enfermagem, Universidade de São Paulo, São Paulo, SP, Brazil. E-mail: valeriac@usp.br.
}

Corresponding Author:

Raquel Silva Bicalho Zunta

Universidade Italo-Brasileira. Faculdade de Enfermagem

Av. João Dias, 2046

Bairro: Santo Amaro

CEP: 04724-003 São Paulo, SP, Brasil

E-mail: rsbzunta@ig.com.br 


\title{
Faturamento de procedimentos de enfermagem em uma Unidade de Terapia Intensiva
}

Os objetivos deste estudo foram: estimar o faturamento gerado pelos procedimentos de enfermagem, em uma unidade de terapia intensiva (UTI), e calcular a porcentagem do faturamento gerado pela enfermagem em relação ao faturamento total da UTI. Tratase de pesquisa exploratório-descritiva, documental, com abordagem quantitativa. Foi realizada em uma UTI geral, de um hospital privado, na cidade de São Paulo. A amostra foi de 159 pacientes. Os procedimentos realizados pela enfermagem foram responsáveis por $15,1 \%$ do faturamento total da UTI, sendo, em média, $11,3 \%$ oriundo do faturamento da prescrição de enfermagem e $3,8 \%$ da prescrição médica. Demonstrar o quanto a enfermagem contribui para o faturamento dos hospitais é informação essencial para os gestores de enfermagem, pois é argumento importante para a obtenção de recursos e garantia de cuidado seguro.

Descritores: Enfermagem; Custos de Cuidados de Saúde; Custos Hospitalares.

\section{La facturación de procedimientos de enfermería en una Unidad de Terapia Intensiva}

\begin{abstract}
Los objetivos de este estudio fueron: estimar la facturación generada por los procedimientos de enfermería en una unidad de terapia intensiva y calcular el porcentaje de la facturación generado por la enfermería en relación a la facturación total de la UTI. Se trató de una investigación exploratoria-descriptiva, documental, con abordaje cuantitativo. Fue realizada en una UTI general, de un hospital privado, en la ciudad de Sao Paulo. La muestra fue de 159 pacientes. Los procedimientos realizados por la enfermería fueron responsables por $15,1 \%$ de la facturación total de la UTI, siendo, en promedio, $11,3 \%$ proveniente de la facturación de la prescripción de enfermería y 3,8\% de la prescripción médica. Demostrar cuanto la enfermería contribuye para la facturación de los hospitales es una información esencial para los administradores de enfermería ya que es un argumento importante para la obtención de recursos y garantizar un cuidado seguro.
\end{abstract}

Descriptores: Enfermería; Costos de la Atención en Salud; Costos de Hospital.

\section{Introduction}

In 1993, the International Council of Nursing (ICN) $)^{(1)}$ appointed, in a document called "Quality, costs and Nursing", the importance of nurses considering costs when assessing the results of their actions, in view of growing economic pressure on global health systems. The same document stated that finance turned into another knowledge domain for nurses, who should clearly demonstrate costs and profitability of their care with a view to arguing on the resources needed for safe care. Profitability "is the level of revenue, i.e. the financial return provided by a certain investment". It can be expressed by the percentage of profits on total investments ${ }^{(2)}$.

Nurses constitute an important decision level in resource allocation, when they decide on service priorities in their work units and on what resources will be used to accomplish them. This is already a reality at some private and public hospitals, where nurses, as managers of their business units, assess needs related to material, physical, human and financial resources, critically analyze the unit's expenses every month, comparing real and budgeted expenses, and participate in next year's budget planning. 
Thus, nurse administrators are increasingly involved in financial decision and budget planning at their institutions and have to manage often scarce (human, material and financial) resources. Therefore, nurses need to seek knowledge in hospital administration and, today, also in accounting in order to manage their costs ${ }^{(3-7)}$.

The emphasis on cost containment and improved health system efficiency have created the explicit need to quantify and justify $\operatorname{costs}^{(3)}$. Nurses in hospitals, however, do not know data about nursing care costs and mainly billing ${ }^{(6,8)}$.

Billing is the "set of revenues expressed in monetary units, which a company obtains through the sale of goods or services in a given period". In other words, "it is the number of units of goods or services sold, multiplied by the unit sales price"(2).

In hospital institutions, nursing care payments are included in daily fees or procedure rates. Daily fees include basic nursing services, understood as usual or routine procedures, such as: bathing, good, washing, among others. Procedure rates, charged separately from daily fees, include nursing procedures like: trichotomy, urinary catheter, dressing and others. Whether these procedures are charged or not and the amounts charged depend on negotiations between service providers and health insurance operators.

These considerations reveal the importance of nurses, who generate revenues through actions prescribed to patients and management of activities performed at their unit, especially at private hospitals, where health operators are the main payment sources.

Although nursing's important contribution to increase hospital billing is appointed, no Brazilian or international research was found to show the percentage of these revenues in a hospital organization. In fact, hospital organizations present their global annual balance sheet without distinguishing these data per services.

This situation motivated the authors to investigate the extent to which nursing contributes to the revenues of an Intensive Care Unit (ICU) at a private hospital. The high cost of maintaining a structure as complex as an ICU has increasingly justified strict cost control in that $\operatorname{area}^{(9)}$. This unit has been responsible for the highest hospital spending, due to the demand for specialized staff, qualified in care delivery to critical patients, and to the continuous inclusion of new technologies; on the other hand, it has been one of the sectors with the highest billing.

\section{Aims}

To estimate the revenues nursing procedures generate per patient at an adult ICU of a general private hospital in São Paulo City, in May and June.

To estimate the percentage of total ICU billing that corresponds to nursing procedures during the months under analysis.

\section{Method}

An exploratory, descriptive and documentary quantitative research was carried out at a general Intensive Care Unit (ICU) of a large 407-bed private hospital in São Paulo City. At the unit, on average, 130 surgical and clinical patients are admitted per month, with a predominance of surgical patients.

Nursing professionals at the unit deliver comprehensive care to patients and perform standardized nursing procedures the nurse prescribes, through the Nursing Care Systemization (NCS), as well as procedures demanded through medical prescriptions.

The billing of nursing procedures demanded through prescriptions is done as a whole, without any specification of the hospital business unit that generated it. In other words, all procedures performed at the ICU and other units the patient was hospitalized at are added up. Therefore, data had to be surveyed from the prescriptions and notes of patients hospitalized at the ICU. Thus, due to information volume, the researchers decided to work with a sample of procedures per patient and then make estimates for the population during the months under analysis.

To constitute the sample, proportional stratified random sampling was used, with a $95 \%$ confidence interval. To calculate the sample, patient data were considered for a two-month period - May and June, with a maximum sample error of $5 \%$. This resulted in a sample of 159 patients. In total, between May and June, 260 patients were hospitalized at the ICU. To permit sample distribution among the strata, the following groups were established: age: up to 60 years and older than 60; hospitalization time and reason for hospitalization. Patients with kidney failure, multiple traumas, digestive hemorrhage, burn, hypertensive emergency, metabolic disorders and angioplasty were grouped under other reasons, as there were few patients in these situations. The patients' distribution across these groups is displayed in Table 1. 
Table 1 - Percentage distribution of patients, subdivided by gender, age range, time and reason for hospitalization, São Paulo, Brazil - 2005

\begin{tabular}{|c|c|c|c|c|c|}
\hline \multirow{2}{*}{ Hospitalization time } & \multirow{2}{*}{ Reason for hospitalization } & \multicolumn{2}{|c|}{ Female } & \multicolumn{2}{|c|}{ Male } \\
\hline & & Up to 60 years & Older than 60 & Up to 60 years & Older than 60 \\
\hline \multirow{7}{*}{1 day } & Postoperative & 8.8 & 8.1 & 5.0 & 8.1 \\
\hline & Acute respiratory failure & 0.4 & 2.3 & 1.5 & 2.3 \\
\hline & Heart failure & 1.5 & 3.1 & 3.1 & 3.5 \\
\hline & Shock & 0.8 & 0.4 & 0.4 & 0.4 \\
\hline & Alteration in consciousness level & 0.4 & 2.7 & 0.4 & 1.9 \\
\hline & Arrhythmia & 0.4 & 3.1 & 0.8 & 0.4 \\
\hline & Others & 0.4 & 2.7 & 1.5 & 3.1 \\
\hline \multirow{7}{*}{ More than 2 days } & Postoperative & 1.9 & 2.3 & 1.5 & 2.7 \\
\hline & Acute respiratory failure & 1.5 & 2.7 & 0.4 & 2.7 \\
\hline & Heart failure & & 0.4 & 1.5 & 0.8 \\
\hline & Shock & 1.2 & 0.8 & 1.2 & 1.2 \\
\hline & Alteration in consciousness level & 0.8 & 1.2 & 1.2 & 2.3 \\
\hline & Arrhythmia & & & 0.4 & 0.4 \\
\hline & Others & 0.8 & 1.5 & 0.8 & 0.8 \\
\hline
\end{tabular}

Samples were randomly drafted in each of the segments. The 159 patients drafted contributed with 834 prescriptions, 400 of which were medical and 434 nursing prescriptions. Less medical prescriptions were included, as some did not describe the nursing procedures of interest to the study, which entail billing for nursing.

After approval was obtained from the hospital's Institutional Review Board under No 088/2005, one of the researchers collected the data between August and October 2005, regarding the period from May to June, as three months is the time needed to close off the billing process of patients' accounts and make the financial report available. The analyzed months were chosen at random.

The following sources were used to obtain the data: patient file, guide for notes in worksheets, financial report.

Patient files were consulted to collect the nursing and medical prescription procedures billed to the patient's account. Nursing notes were read to compare whether the prescribed procedures were written down, as the procedure is only billed if properly registered, as recommended in the Guide for notes in worksheets.

The procedures deriving from the medical prescription that demand nursing procedures and generate billing were: nasogastric catheter (NGC), nasoenteral catheter (NEC), indwelling urinary catheter (IUC), intermittent urinary catheter (INUC), enteral diet $(E D)$, parenteral diet (PD), inhalation, Dextro (blood glucose test through peripheral access), peritoneal dialysis, electrocardiogram (ECG), enteroclysis and placement of external pacemaker.
These procedures are described, together with the amount of material to be used, in the Manual of quality procedures (QP), established by the ICU. Their charges are also established in the Guide for notes in worksheets. Material expenses, however, can vary depending on the patients' needs and the qualification of the staff who is performing the procedure. The procedures the nurse prescribes are: warming limbs, aspirating, installing a water mattress, putting on compression stockings, placing transparent films - heels, placing transparent films - sacrum, applying dressings, performing oral hygiene, installing thermal blanket, placing trackcare (closed aspiration system), placing hydrocolloid, lubricating lips, bathing with bathing gloves, performing comfort massage, ostomy cleaning, limb restraining, installing egg crater mattress, installing vamp (device, closed system for glucose collection at interals of 4 hours or less, during 24 hours), placing an ice pack and placing a uripen.

The financial report is where the hospitalization forms, health insurance authorizations and patient's bill are filled, including data on daily charges, fees, nursing procedures, hospital procedures, equipment, gases, drugs and material.

Two collection instruments were elaborated to register the information. The first served to record information from the nursing prescription, with the following information: collection month, patient code, hospitalization days, content of nursing prescription, material value, quantity (total sum of procedures), total amount (material value multiplied by total number of procedures accomplished), labor value and total procedure billing (sum of total labor price and total 
material price). The second served to collect notes from the medical prescription, with the same items.

A pretest was performed on ten files and bills of patients who had already been discharged. The author completed the instruments with the data from the abovementioned files, analyzed and validated them together with professionals from the hospital's Audit and Accounts department.

For data analysis, descriptive analysis of the study variables was adopted, with distributions and frequencies, descriptive measures, means and standard deviation. After completing the instruments with the data, these were transferred to Excel worksheets for storage.

To avoid disseminating amounts of ICU revenues, on the institution's request, the estimated contribution of nursing procedures was processed in reais and percentages.

\section{Results}

Descriptive data analysis was performed using qualitative variables for relative frequencies (percentages), and the absolute frequency $(\mathrm{N})$ of classes for each qualitative variable. For the quantitative variables, means and medians were used to summarize the information, and standard deviations, minimum and maximum values to indicate data variability.

As for the clients' characteristics, patient distribution between the two months under analysis showed that 80 patients $(50.3 \%)$ were hospitalized in May and 79 in June $(49.7 \%)$, totaling 159 . There could be a difference due to the larger number of hospitalizations, as June borders on the holiday period, but no difference was found between May and June. Thus, patients were distributed similarly between both months.

Regarding gender, no relevant difference was found between percentages. Male and female groups behaved similarly. As for the age variable, a larger difference was found between the percentages of patients older than 80 and other patients, as well as a predominance of patients between 60 and 80 years of age.

With regard to the reason for hospitalization variable $(n=159)$, a significant percentage difference was found, mainly showing postoperative patients (38.4\%), followed by patients with acute respiratory failure (13.8\%) and heart failure $(13.8 \%)$, while the remainder behaved similarly. This predominance of postoperative patients can be associated with the hospital clients' profile, which mostly includes surgical patients.

Results for days of hospitalization show the predominance of patients hospitalized for one day, with 95 patients $(59.7 \%)$.

As for health insurance, the 159 patients were distributed among 25 operators, with one representing $27.7 \%$. Although most prices are the same, item billing may differ depending on the type of insurance, that is, the same procedure, material or drug may be billed differently, in function of agreements made between the insurer and the hospital, and also because some prices are updated, while others are maintained.

Billing of nursing prescription procedures is presented in Table 2, joining amounts for both months. These statistics refer to one patient's summarized value. Thus, one may say that, on average, $\mathrm{R} \$ 85.56$ are billed per patient for limb warming.

Table 2 - Mean billing in reais for nursing prescription procedures per patient in May and June, São Paulo, Brazil 2005

\begin{tabular}{|c|c|c|c|c|c|}
\hline & Mean & Median & Standard deviation & Minimum & Maximum \\
\hline Cardiac debit & $1,290.92$ & $1,121.54$ & 587.61 & 623.82 & $2,249.27$ \\
\hline Installing VAMP & 761.28 & 761.28 & 348.31 & 380.64 & $1,141.92$ \\
\hline Trackcare & 655.12 & 568.92 & 551.79 & 206.88 & $1,758.48$ \\
\hline Humidifier filter & 550.42 & 453.34 & 463.42 & 100.80 & $1,915.20$ \\
\hline Pulmonary capillary pressure & 506.29 & 458.28 & 277.53 & 203.28 & 905.31 \\
\hline Dressings & 414.36 & 148.38 & 689.09 & 8.43 & $4,984.10$ \\
\hline Air mattress & 289.23 & 133.04 & 326.33 & 53.55 & $1,645.38$ \\
\hline Ostomy cleaning & 233.42 & 189.55 & 142.43 & 86.65 & 485.10 \\
\hline Compression stockings & 148.83 & 150.00 & 2.28 & 144.06 & 150.00 \\
\hline Thermal blanket & 134.77 & 124.11 & 16.90 & 124.11 & 156.10 \\
\hline Aspirating & 101.03 & 46.39 & 145.80 & 10.68 & 650.87 \\
\hline Limb warming & 85.56 & 14.45 & 241.89 & 1.56 & 936.00 \\
\hline Hydrocoloid & 81.76 & 29.04 & 153.56 & 29.04 & 619.52 \\
\hline Bath gloves & 48.80 & 22.99 & 69.52 & 2.42 & 377.52 \\
\hline Transp. films sacrum & 38.49 & 31.39 & 17.29 & 28.80 & $\begin{array}{c}125.56 \\
\text { (continu }\end{array}$ \\
\hline
\end{tabular}


Table 2 - (continuation)

\begin{tabular}{|c|c|c|c|c|c|}
\hline & Mean & Median & Standard deviation & Minimum & Maximum \\
\hline Egg crater mattress & 36.67 & 36.00 & 1.06 & 36.00 & 38.00 \\
\hline Comfort massage & 35.94 & 34.99 & 6.66 & 434.49 & 104.97 \\
\hline Transp. films heels & 35.02 & 28.60 & 17.36 & 13.12 & 94.17 \\
\hline Ice pack & 32.54 & 32.54 & 0.00 & 32.54 & 32.54 \\
\hline Dextro & 13.01 & 5.72 & 25.01 & 0.99 & 214.11 \\
\hline Oral hygiene & 11.95 & 10.79 & 8.55 & 10.19 & 106.48 \\
\hline Limb restraining & 7.92 & 4.68 & 7.65 & 1.46 & 26.56 \\
\hline Placing uripen & 2.58 & 2.58 & 0.00 & 2.58 & 2.58 \\
\hline Lubricating lips & 1.01 & 0.99 & 0.08 & 0.97 & 1.33 \\
\hline
\end{tabular}

The results shown in Table 2 reveal that the nursing prescription procedures that most contributed to ICU billing were: checking cardiac debit, installing VAMP, placing trackcare, exchanging the humidifier filter, checking pulmonary capillary pressure and applying dressings. The procedure that showed the highest amount in reais was checking cardiac debit. This process generated, on average, $\mathrm{R} \$ 1,290.92$, ranging from $R \$ 623.82$ to $R \$ 2,249.27$, and is performed when the patient is using a swan ganz catheter. Although the amount is small, billing was higher due to the high cost of the procedure. The mean billing for dressing, which is one of the most frequent nursing procedures, corresponded to $\mathrm{R} \$ 414,36$, which can range from $R \$ 8.43$ to $R \$ 4,984.10$. In view of the large number of dressings per patient per day, one may say that, regarding cardiac debit, total billing for this procedure was higher.

Next, Table 3 shows billing for medical prescription procedures, joining amounts for both months.

Table 3 - Mean billing in reais for medical prescription procedures per patient in May and June, São Paulo, Brazil 2005

\begin{tabular}{|c|c|c|c|c|c|}
\hline & Mean & Median & Standard deviation & Minimum & Maximum \\
\hline PD & $3.139,51$ & $2.021,91$ & $3.288,47$ & 448,32 & $10.276,66$ \\
\hline Enteral diet & $1.448,57$ & 786,67 & $1.508,20$ & 285,10 & $6.410,52$ \\
\hline Peritoneal dialysis & $1.031,95$ & $1.031,95$ & 0,00 & $1.031,95$ & $1.031,95$ \\
\hline Pacemaker & 242,56 & 229,88 & 110,87 & 128,23 & 369,56 \\
\hline Inhalation & 165,40 & 108,56 & 145,28 & 21,78 & 556,53 \\
\hline Dextro & 140,42 & 53,82 & 240,8 & 5,89 & $1.795,68$ \\
\hline NEC & 113,90 & 125,93 & 27,39 & 64,97 & 170,93 \\
\hline ECG & 79,59 & 50,70 & 65,28 & 41,59 & 394,80 \\
\hline Enteroclysis & 54,60 & 46,52 & 24,68 & 30,57 & 112,99 \\
\hline NGC & 47,50 & 32,51 & 23,37 & 26,90 & 100,48 \\
\hline IUC/INUC & 67,00 & 65,77 & 13,88 & 25,00 & 98,17 \\
\hline
\end{tabular}

Table 3 shows that the medical prescription procedures the nursing staff performed and which most contributed to ICU billing were: enteral diet, parenteral diet and peritoneal dialysis. The procedure with the most significant amount in reais was parenteral diet, with an average $R \$ 3,139.51$, ranging from $R \$ 448.32$ to $\mathrm{R} \$ 10,276.66$. Both enteral and parenteral diets are highcost products ICU patients frequently consume. Also, the dextro procedure corresponded to a mean amount of $R \$ 140.42$, ranging from $R \$ 5.89$ to $R \$ 1,795.68$, due to the number and frequency of times it is performed per patient.
Table 4 shows amount billed for each patient and total billing. To calculate total billing, the amount was inferred based on the total number of hospital patient during both periods. Calculations were weighted by the percentage of patients per month, per gender and per age for each diagnosis.

On average, total billing amounted to $R \$ 8,918.30$ per patient, which can range from $\mathrm{R} \$ 799.37$ to $\mathrm{R} \$ 105,891.86$; the amount billed through nursing procedures deriving from nursing prescriptions corresponded to $R \$ 1,230.33$ per patient, while the amount resulting from medical prescriptions was $\mathrm{R} \$ 508.57$ per patient. 
Inferring estimating total billing for 260 patients, this resulted in $R \$ 2,318,757.22$. The mean total billing per patient was $R \$ 8,918.30$, with an average $R \$ 1,738.90$ for nursing procedures only. Differences between these two amounts correspond to daily rates, fees, hospital procedures, gauze, material and drugs.

Table 4 -Distribution of total amounts billed in reais, per patient, in May and June, São Paulo, Brazil - 2005

\begin{tabular}{lcc}
\hline & Mean per patient & Total for all patients \\
\hline Billing - medical prescription + nursing prescription & $1,738.90$ \\
Billing Nursing prescription procedures & $1,230.33$ \\
Nursing procedures - labor & 757.68 & $319,115.95$ \\
Nursing procedures - material & 477.41 & $195,758.97$ \\
Billing Medical prescription procedures & 508.57 & $124,127.48$ \\
Medical procedures - labor & 205.87 \\
Medical procedures - material & 302.70 \\
Total Billing & $83,918.30$ \\
\hline
\end{tabular}

Data in Table 4 show that the total amount billed for nursing procedures, resulting from nursing prescriptions, for all patients, corresponded to $\mathrm{R} \$ 319,886.46$, while the total amount billed for nursing procedures deriving from medical prescriptions amounted to $R \$ 132,229.49$. Total billing for nursing procedures equaled $R \$ 452,115.99$ for 260 patients, in May and June.

Estimated for amounts billed in reais were presented above. Table 5 shows the percentages of each procedure in total billing. Thus, through descriptive statistics for the percentages of interest, it can be observed that, on average, $11.3 \%$ of billing for each patient derived from nursing prescription, which can range between $1.8 \%$ and $34.8 \%$ per patient; and that $3.8 \%$ of billing for each patient derived from medical prescriptions, ranging from $0 \%$ to $20 \%$.

Table 5 - Percentage distribution of billing from medical and nursing prescriptions, material and labor, São Paulo, Brazil - 2005

\begin{tabular}{|c|c|c|c|c|c|}
\hline & Mean & Median & Standard deviation & Minimum & Maximum \\
\hline Billing from NP & 11.3 & 10.6 & 5.9 & 1.8 & 34.8 \\
\hline Billing from MP & 3.8 & 3.0 & 3.6 & 0.0 & 20.0 \\
\hline Billing from NP - Labor & 5.4 & 4.2 & 4.4 & 0.0 & 22.4 \\
\hline Billing from NP - Material & 5.9 & 4.8 & 3.7 & 1.7 & 23.7 \\
\hline Billing from MP - Labor & 1.4 & 1.0 & 1.5 & 0.0 & 7.0 \\
\hline Billing from PM - Material & 2.4 & 1.6 & 2.6 & 0.0 & 13.3 \\
\hline
\end{tabular}

Thus, on average, billing from nursing procedures can contribute to $15.1 \%$ of total billing per patient, ranging from $1.8 \%$ to $54.8 \%$. Through inference, one may say, therefore, that nursing contributed with an average $15.1 \%$ of total ICU billing. The study showed that $15.1 \%$ ( $11.3 \%$ from NP and $3.8 \%$ from MP) of ICU billing, obtained from each patient, derived from nursing procedures.

\section{Discussion}

Discussion this theme represents a great challenge, due to the lack of specific literature. Besides, it is practically a new reality for nurses who, today, are considered managers of their business units. Hence, the present data cannot be compared with data from other similar studies.

Nursing performs many procedures, especially at the ICU, where complex and critical patients are present. These procedures are registered in the patients' files, through which nursing professionals show the quality and quantity of their work, also permitting knowledge on the resources allocated to each intervention. Hence, registered care represents ethical, legal and, today, financial support for professionals, patients, health organizations, as well as insurance companies and health plans.

Although the study showed that, on average, $15.1 \%$ of ICU billing from each patient derived from nursing procedures, it is known that this percentage is higher in 
practice, as many other procedures are "embedded" in daily rates and room fees, such as: bathing, help with feeding, among others.

In hospital organizations, patient bills include daily rates, fees, material and drugs, distinguished per cost center, which is not the case for nursing procedures, which are displayed as a whole. This practice hampers rapid knowledge on nursing billing in each sector. For the sake of this research, information had to be collected from nursing notes in order to distinguish ICU procedures.

Thus, it is suggested that all items charged on the patient bill be specified per Cost Center, which will facilitate monitoring by nurses at the study hospital and also future studies.

\section{Conclusion}

Through this research, the revenues nursing procedures generated at an ICU could be estimated, as well as their percentage in total billing.

Showing the extent to which nursing contributes to unit billing is one way to disclose these professionals' vital role in the results of a business unit and in the organization as a whole. Also, it serves as a management and negotiation tool for strategic planning of physical, human, material and financial resources at the hospital.

Thus, it is important for nurses to know how nursing care costs are appropriated and to show their importance not only in cost reduction, but also in revenue generation. Therefore, nurses should increasingly involve in these issues, seeking training needed to develop cost calculation methods through which the true cost of nursing care for hospital revenues can be measured.

\section{References}

1. Consejo Internacional de Enfermeras. La calidad, los costos y la enfermeria. Geneva: Consejo Internacional de Enfermeras; 1993.

2. Sandroni P. Dicionário de administração e finanças. São Paulo: Best Seller; 2001. 577 p.

3. Secoli SR, Padilha KG, Litvoc J. Análise custo-efetividade da terapia analgésica utilizada na dor pós-operatória. Rev. Latino-Am. Enfermagem. 2008;16(1):42-6.

4. Francisco IMF, Castilho V. A enfermagem e o gerenciamento de custos. Rev EsC Enferm USP. $2002 ; 36(3): 240-4$.

5. Baptista CMC, Castilho V. Cost survey of procedure with Unna boot in patients with venous ulcer. Rev. Latino-Am. Enfermagem. 2006;14(6):944-9.
6. Secco LM dal, Castilho V. Expenditure survey on continued veno-venous hemodialysis procedure in the intensive care unit. Rev. Latino-Am. Enfermagem. 2007; 15(6): 1138-43.

7. Bittar E, Castilho V. O custo médio direto do material utilizado em cirurgia de revascularização do miocárdio. Rev Assoc Med Bras. 2003;49(3):255-60.

8. Nakao JRS. Estudo do pagamento da assistência de enfermagem hospitalar na rede privada no município de Ribeirão Preto [tese de doutorado]. Ribeirão Preto (SP): Escola de Enfermagem de Ribeirão Preto da Universidade de São Paulo; 1995.

9. Telles SCR, Castilho V. Custo de pessoal na assistência direta de enfermagem em unidade de terapia intensiva. Rev. Latino-Am Enfermagem. 2007;15(5):1005-9. 